\title{
University Students' Perceptions of Generational Issues in the Workplace
}

\author{
Dr. Kathryn Woods \\ Associate Professor, Leadership and Organizational Administration \\ Austin Peay State University
}

\begin{abstract}
This study examined university students' perceptions of generational issues in the workplace. Baby Boomers are retiring rapidly (their knowledge and experience retiring along with them), and Millennials are now the largest generational group represented in the workforce. Students at a mid-sized university in the southeast region of the United States, majoring in Leadership or attending a leadership skills development workshop, were surveyed to determine their views on challenges and opportunities that exist due to the current generational landscape of the workforce. Results of the study indicated that reconciling various perspectives was both the top challenge and benefit when working with members of other generations, and that opportunities for reciprocal mentorship were valued by members of each generation surveyed. Recommendations for leadership educators and future researchers are provided.
\end{abstract}

\section{Introduction}

The National Leadership Education Research Agenda (Andenoro, et al, 2013) was created by the Association of Leadership Educators in 2011 to serve as a guide for educators and practitioners as they conduct and apply research in leadership education, develop and update leadership curriculum for students, and continue to refine the meaning of leadership education as a discipline. The authors of the agenda identified teaching, learning, and curriculum development to be the first priority in leadership education during the 2013 - 2018 time period. The agenda highlights the importance of engaging in research to study student and faculty experiences in leadership education, including learning and programmatic outcomes, curricular and co-curricular learning environments, and the effectiveness of instructional and assessment strategies. Another priority mentioned on the agenda is the sociological development of leaders, followers, and learners. The diversity of learners and changing organizational dynamics were identified as two of the main challenges in this area. These priorities and their corresponding challenges and opportunities coupled with a rapidly changing landscape of generations represented in the workforce provided the basis for the present study.

Employers' expectations of new college graduates continue to expand beyond the traditional training in the designated subject area relative to the industry. Modern companies now anticipate that degree-holders will be well-versed in soft skills, including the ability to appreciate and capitalize on diversity in the workforce (Fabris, 2015). While many college students believe that they have developed these skills during their degree program, employers often report that they find new graduates to be lacking in these areas, particularly in teamwork, communication, and the ability to work with diverse populations (Fabris, 2015; Jaschik, 2015; O'Shaughnessy, 2015). Millennials are frequently reported as being the generation most tolerant 
of diversity, leaving academics and employers wondering why they are having trouble working with individuals who are unlike themselves (Dishman, 2015; Frey, 2016). As colleges evaluate ways to improve students' abilities to enter the workforce with the skills needed to work with others, leadership and diversity classes must be placed directly in the spotlight.

Millennials are now the largest group represented in the workforce (Fry, 2015). In a time of generational transition in the workforce, the focus on diversity has presumably never been more important. Stakeholders of the higher education community are making an effort to determine what students already know and appreciate about diversity, and how we can build on their existing knowledge and perceptions (Fabris, 2015). The purpose of this study was to answer the following research question: What are university students' current perceptions regarding generational differences in the workplace? The principal investigator of this study was particularly interested in analyzing the data collected to determine whether current students who belong to different generations have different perceptions about the challenges and opportunities afforded from working in a multi-generational workforce.

\section{Literature Review}

The Modern Generational Landscape. Generally accepted birth years for the largest generational groups currently represented in the workforce are as follows: Baby Boomers are those born between 1946 and 1964, members of Generation X were born between 1965 and 1980, and Millennials were born between 1981 and 1996 (Dimock, 2018). Fry (2015) has reported that while the workforce has always consisted of multiple generations, modern times show a rapid shift in the age-range of employees. He reported that as Baby Boomers retire, their share of the makeup of the workforce has declined rapidly in the last several years, and Millennials surpassed them in number for the first time in 2014. He also reported that in 2015, as the disproportionately-large Millennial group continued to join the workforce, they overtook the Gen Xers. Predictions for the makeup of the workforce in the future vary, but many researchers report that between $50 \%$ and $75 \%$ of all employees could be Millennials sometime between 2020 and 2025 (Dews, 2014; Dishman, 2015; Donston-Miller, 2016; Lacey, Toossi, Dubina, \& Gensler, 2017; Lynch, 2008).

As always, some general differences in skills and values exist between the generations currently represented in the workplace. A study by Gursoy, Maier, and Chi (2008) revealed that Baby Boomers valued authority, hierarchy, patience, and loyalty, while Gen Xers tended to rebel against authority and valued recognition, promotion, and work-life balance. The Millennials reported strong beliefs in the value of teamwork, optimistic predictions for the future, and maintaining trusting relationships with supervisors (Dishman, 2015). Each generation has been reported as being more tolerant of diversity than the one prior, with Millennials frequently cited as the most tolerant and inclusive generation to date (Dishman, 2015; Frey, 2016).

Reciprocal Mentoring. Several studies have been conducted to assess how different generations interact in modern, diverse workplaces. Some studies report that there are many positive outcomes when employees are educated about the values and strengths of each generation, and these studies provide support for the implementation of effective reciprocal mentoring programs (Beutell and Wittig-Berman, 2008; Knight, 2014; Lu and Gursoy, 2016; 
Thompson and Gregory, 2012; Twenge, 2010). As the name suggests, these programs exist to allow both parties - generally one long-tenured employee and one new employee - to draw from each other's strengths. These relationships frequently occur across the generations. A Baby Boomer, for example, might benefit from being paired with a Millennial in a mentorship program by learning some new technological advances, while the Millennial could gain insight about the status of current client relationships and internal processes from their more experienced peer (Beutell and Wittig-Berman, 2008; Knight, 2014).

While employees have reported positive results gained from formal and informal reciprocal mentoring programs mentioned above, popular media continues to report that generations are not without criticism and stereotypes for one another. This type of media coverage could exacerbate stereotypes that are not based on data derived from scientific studies. While Millennials have long been touted as harboring feelings of extreme entitlement as a generation, they are also the most-studied generation in the workplace (Donston-Miller, 2016; Huppke, 2018). Researchers consistently report that reciprocal mentoring is a primary best practice when organizations want to make a concerted effort to retain their Millennial employees (Meister \& Willyerd, 2010; Zimmerman, 2016).

In contrast, other researchers have reported a lack of support for consistent evidence of generational differences in the workplace, citing instead that it is much more difficult to separate the effects of age (life stage, experience, maturity level, etc.), period (relevant historical events), and cohort (shared experiences), than to label groups with stereotypes that hold only slight truths (Costanza \& Finkelstein, 2015; Knight, 2014). Some even contend that generational stereotypes are "sold" to the public by the media and used to leverage various business strategies (Perry, Golom, \& McCarthy, 2015). As scientifically valid research continues to emerge on this topic, the generations represented in the workforce continue to shift, and best practices suggested to organizational leaders on how to handle issues related to diversity shift along with them.

Teaching Diversity. As Millennials gain more work experience and are increasingly moving into leadership roles in their organizations, they are reporting difficulties in managing members of older generations (Heppke, 2018). While some contend that understanding generational differences in the workforce is as important as the focus on any other cultural differences that exist between employees, others argue that promoting the concept of generational differences only serves to exacerbate stereotypes. Some lingering questions surrounding this topic include: What do students think about the differences between generations in the workplace? Where did their ideas come from? What, if anything, are we teaching them about these differences in leadership programs?

While many leadership education programs include a diversity component, the content of those components can vary widely. While traditional diversity textbooks have touched on agerelated diversity issues for years, the last decade has seen a rise in coverage that touches on perceived differences in the generational groups represented in the workforce today (Brown, 2016). With an increase in the study of generations and their preferences, perceptions, values, and attitudes, and the rapid shift in the generational landscape of the workforce, educating future organizational leaders on diversity issues has become both more important and more difficult to 
stay current in knowledge and instruction (Chamberlin, 2009; Lynch, 2016; "The Whys and Hows," 2015).

\section{Conceptual Framework}

To date, a proven theory of generationally-based differences has not been generally accepted in the social sciences. The conceptual framework used to understand and interpret the findings in this study was derived from the body of knowledge surrounding changing organizational dynamics, with specific regard to the changing generational landscape of the workforce, and the responsibility of leaders to manage these dynamics (Dishman, 2015; Donston-Miller, 2016; Lynch, 2008). Currently, the issues of concern for leaders surrounding this topic include succession planning due to the rapid pace in which Baby Boomers are retiring (their knowledge and experience retiring along with them), the predictions that Millennials are such a populous generations that they will comprise up to $75 \%$ of the workforce in the next 10 years, reported problems with Millennials managing members of older generations, and assessing and revising efforts to retain existing employees and recruit new ones (Abrams \& von Frank, 2014; Dews, 2014; Fry, 2015; Lacey, Toossi, Dubina, \& Gensler, 2017).

\section{Methods}

Data Collection. This study employed a survey to assess perceptions. Students were asked whether they had previously discussed the challenges and opportunities of working in a multi-generational workforce in a classroom setting, and to share their thoughts and experiences about the challenges and opportunities in working with members of other generations, if applicable.

Other demographic information was collected on the survey to use in a comparison of the respondents' perceptions. The survey contained questions to determine participants' age range (generation), gender, and applicable student rank (high school; undergraduate: freshman, sophomore, junior, or senior; graduate). The age ranges on the survey were updated from 2016 to 2017 to continue to capture the ages spanning each generation.

Participants. Survey participants were selected via a convenience sample of students from a mid-sized university in the southeast region of the United States. The survey was given to students who attended on-campus leadership skill workshops in the Spring 2016 and Spring 2017 terms. The survey was also given to undergraduate students majoring in Leadership and Organizational Administration and graduate students majoring in Strategic Leadership during all terms from Spring 2016 through Fall 2017. Students who did not agree to the informed consent statement or were not over the age of 18 were excluded from the study prior to taking the survey.

In total, 44 students attended the leadership skill workshops, and 23 surveys were collected. Total enrollment in the Leadership and Organizational Administration and Strategic Leadership major courses surveyed in was 216, and 100 surveys were completed. A total of 123 surveys were collected, generating a response rate of $47 \%$. Nine surveys were excluded from data analysis due to incomplete and/or illegible information, leaving an $N$ of 114. 


\section{Results}

Demographic and basic information reported by respondents is summarized below in Table 1 .

Table 1. Descriptive Statistics

\begin{tabular}{|c|c|c|}
\hline & \multicolumn{2}{|c|}{$\begin{array}{l}\text { Total Sample } \\
\qquad(N=114)\end{array}$} \\
\hline & & $\%$ OF TOTAL \\
\hline & $n$ & SAMPLE \\
\hline \multicolumn{3}{|l|}{ GENERATION } \\
\hline Baby Boomers & 15 & $13 \%$ \\
\hline Generation X & 48 & $42 \%$ \\
\hline Millennials & 51 & $45 \%$ \\
\hline \multicolumn{3}{|l|}{ GENDER } \\
\hline Male & 70 & $61 \%$ \\
\hline Female & 42 & $37 \%$ \\
\hline Did not indicate & 2 & $2 \%$ \\
\hline \multicolumn{3}{|l|}{$\begin{array}{l}\text { STUDENT } \\
\text { CLASSIFICATION }\end{array}$} \\
\hline High School & 1 & $1 \%$ \\
\hline Freshman & 2 & $2 \%$ \\
\hline Sophomore & 2 & $2 \%$ \\
\hline Junior & 15 & $13 \%$ \\
\hline Senior & 51 & $45 \%$ \\
\hline Graduate & 43 & $38 \%$ \\
\hline
\end{tabular}

As outlined in the table above, the sample was made up of members of three generations - Baby Boomers (13\%), Generation X (42\%), and Millennials (45\%). Also of note, the sample was comprised of more males $(61 \%)$ than females $(42 \%)$, and mainly included undergraduate upperclassmen $(58 \%)$ and graduate-level students $(38 \%)$.

Regarding the survey question, "Have you learned about and/or discussed the challenges and opportunities that are present when working with individuals from different generations in a classroom or online course setting?" students were provided with "yes" and "no" response fields. Eighty-six students (75\%) responded "yes", indicating that they had some experience learning about or discussing the implications of a multi-generational workforce in an academic environment. The remaining 28 students $(25 \%)$ indicated that they had no such experience.

Similarly, the survey question, "Have you worked in a setting in which you regularly interacted with individuals from other generations?" provided "yes" and "no" response fields for the students. Nearly all (110 students, 96\%) of the students surveyed indicated that they had experience working with individuals from other generations. 
Perceived Challenges Faced in the Multi-Generational Workforce. The comments provided in the open-ended text fields for the question "From your perspective, what do you think is the main challenge in working with individuals from other generations? Why?" were also analyzed, and the following themes in perceptions of challenges were identified:

Communication styles, technology skills, values and beliefs, work ethic, and perspective. Table 2 summarizes the totals of the comments provided by each generational group represented in the population for this study.

Table 2. Challenges Faced when Working with Other Generations

\begin{tabular}{|c|c|c|c|c|c|c|}
\hline \multicolumn{7}{|c|}{$\begin{array}{c}\text { Total Sample } \\
(N=114)\end{array}$} \\
\hline \multirow{2}{*}{$\begin{array}{l}\text { Challenges } \\
\text { Identified } \\
\end{array}$} & \multicolumn{2}{|c|}{ Baby Boomers } & \multicolumn{2}{|c|}{ Gen Xers } & \multicolumn{2}{|c|}{ Millennials } \\
\hline & $n=15$ & $\begin{array}{c}\text { \% of } \\
\text { subgroup }\end{array}$ & $n=48$ & $\begin{array}{c}\% \text { of } \\
\text { subgroup }\end{array}$ & $n=51$ & $\begin{array}{c}\% \text { of } \\
\text { subgroup }\end{array}$ \\
\hline $\begin{array}{c}\text { Values and } \\
\text { Beliefs }\end{array}$ & 2 & $13.3 \%$ & 10 & $20.8 \%$ & 7 & $13.7 \%$ \\
\hline Communication & 2 & $13.3 \%$ & 11 & $23 \%$ & 9 & $17.6 \%$ \\
\hline Work Ethic & 4 & $26.6 \%$ & 7 & $14.6 \%$ & 3 & $5.8 \%$ \\
\hline Tech Skills & 3 & $20 \%$ & 8 & $16.6 \%$ & 13 & $25.5 \%$ \\
\hline Perspective & 5 & $33.3 \%$ & 13 & $27.1 \%$ & 21 & $41.2 \%$ \\
\hline
\end{tabular}

The following student comments from the survey provide examples of these themes:

Communication styles. Communications...younger generations do not make eye contact while talking. (Baby Boomer)

Communication methods, approach, and mannerisms are different. Email versus inperson or by phone, there are different default approaches dependent on generations. Words used when speaking to one another tend to be more casual with millennials. It is always important to learn how each generation tends to communicate and what methods are used during different scenarios. (Gen Xer)

Sometimes I am talked down to and feel inadequate, older generations are impatient... (Millennial)

Technology skills. Differences in technological knowledge is one of the main challenges in working with individuals from other generations in relation to my job. For older generations, it can be difficult to help them understand how to use the technology they need. For younger generations, the challenge is that they sometimes think they understand more than they do. (Gen Xer) 
Different...levels of technological skill make it harder to work with other generations. I am used to working with computers, cell phones, etc. and the people I work with do not know how to use them very well. (Millennial)

Values and beliefs. The main challenge is understanding the culture of different generations. (Baby Boomer)

The misinformation and liberal indoctrination of younger generations by academia and the media. (Gen Xer)

The way they were brought up can be very different. Their ideas of what's right and wrong varies and the way of doing things have changed as time has gone on and it might not have changed for them. (Millennial)

Work ethic. I am old school meaning that work ethics from my time involved more physical work than it does today. People my age are more prone to do whatever it takes to get the job done than those in other varying generations. It seems the younger the work force, the less productive they are when it comes to physical labor. I have a difficult time with this as in my eyes it is considered laziness or the lack of parenting which teaches them what real work is. Not all generations are this way, it just seems to be mainly those 35 and under. I have noticed that those who had parents who taught them the real value of work, do better than others. (Baby Boomer)

In a younger individual, I don't feel they have the same work ethic and they seems to question everything. In the older generation, they are more set in their ways and do not handle change as freely. (Gen Xer)

Perspective. The younger generation is more educated and therefore think things should always go their way. (Baby Boomer)

Frame of Reference. It is difficult at times to make reference to world events and use them as a learning tool when things once thought common knowledge are not. (Gen Xer) Individual egos. Older generations believe they have more experience and therefore have more knowledge of the field than the younger generations. Younger generations believe their education is more relevant to the times than that of older generations so they feel they know more in the field. (Millennial)

Perceived Opportunities for the Multi-Generational Workforce. The comments provided in the open-ended text fields for the question "From your perspective, what do you think can be gained by working with individuals from other generations? Why?" were analyzed, and the following themes in perceptions of opportunities were identified: Knowledge, perspective, reciprocal mentoring, and work ethic. Table 3 summarizes the comments provided by each generational group represented in the population for this study. 
Table 3. Opportunities Realized in Working with Other Generations

\begin{tabular}{|c|c|c|c|c|c|c|}
\hline \multicolumn{7}{|c|}{$\begin{array}{l}\text { Total Sample } \\
(N=114)\end{array}$} \\
\hline \multirow{2}{*}{$\begin{array}{l}\text { Challenges } \\
\text { Identified } \\
\end{array}$} & \multicolumn{2}{|c|}{ Baby Boomers } & \multicolumn{2}{|c|}{ Gen Xers } & \multicolumn{2}{|c|}{ Millennials } \\
\hline & $n=15$ & $\begin{array}{c}\% \text { of } \\
\text { subgroup }\end{array}$ & $n=48$ & $\begin{array}{c}\% \text { of } \\
\text { subgroup }\end{array}$ & $n=51$ & $\begin{array}{c}\% \text { of } \\
\text { subgroup }\end{array}$ \\
\hline Work Ethic & 0 & $0 \%$ & 3 & $6.3 \%$ & 2 & $3.9 \%$ \\
\hline Knowledge & 4 & $26.7 \%$ & 18 & $37.5 \%$ & 25 & $49 \%$ \\
\hline $\begin{array}{l}\text { Reciprocal } \\
\text { Mentoring }\end{array}$ & 5 & $33.3 \%$ & 20 & $41.7 \%$ & 14 & $27.5 \%$ \\
\hline Perspective & 7 & $46.7 \%$ & 25 & $52.1 \%$ & 28 & $54.9 \%$ \\
\hline
\end{tabular}

The following student comments from the survey provide examples of these themes:

Knowledge. The younger generation have a lot of good and fresh ideas, we can gain a lot from their knowledge. (Baby Boomer)

The older generation is full of knowledge that I can benefit from. They have seen and experienced things that I haven't. (Gen Xer)

Working with individuals from other generations can help because of how much experience the older individual has and they can work with younger individuals and pass on more insight from their experiences to the younger generations. (Millennial)

Perspective. A reflection as to how I was at their age and how I handle situations so much differently; also one can see how quick this generation is growing up and how informed they are about things that I personally didn't know about until I was married or much older. (Baby Boomer)

New perspectives and old experience can lead to great ways of dealing with problems. The older experience can let the newer one know what hasn't worked so that the new perspective can work towards another solution. (Gen Xer)

Ifeel like I get to learn from them. They have been here so long they know the system inside and out. They know the families and the communities. I think it's a great thing that there are so many people that have been in my work place for so long. It gives me a feeling that it is a great place to be and stay. (Millennial)

Reciprocal mentoring. The more experienced, the more I can learn from them. Both older and younger generations provide valuable insight I can learn from. (Baby Boomer)

From younger generations you get that stamina, a better, faster way to complete projects. From older generations you have the stability, experience, and knowledge that a certain method will work no matter the situation. (Gen Xer) 
A more effective team. A team that is made of more than one generation can benefit because of different levels of experience and education. Older generations may have more experience and can teach younger generations how to deal with specific situations that they may not have encountered yet. Younger generations may have a better understanding of new technology that is being used in the work place and can teach the older generations how to use it. (Millennial)

Work ethic. In working with those from an older generation, I see the value that they place on work. I see the integrity, the work ethic, the attitude is different. What you gain from the older generation is the value they place in work, what you gain from the younger generation is that everything doesn't always have to be taken so seriously. (Gen Xer)

\section{Discussion}

In the present study, students from all generational groups represented reported that both the main challenge and benefit when working with individuals from other generations was perspective. Many comments from students mentioned challenges and opportunities that varied perspectives bring to teamwork and problem-solving. Dittmann (2005) suggested that employees should be aware of the strengths each generation brings to the table in their workplace. She highlighted an improvement in teamwork in organizations when the team members represent multiple generations, as multiple perspectives can improve problem-solving and increase team creativity. She contended, "If we don't talk about why we're different and our different perspectives, we don't come to the best decisions" (para. 18). Similarly, Knight (2014) emphasized the importance of being aware of generational tension among employees and helping them recognize their distinct strengths and how they can benefit the organization. Throughout the literature, researchers suggested that leaders point out rather than downplay the differences that may exist between members of different generations, which may contrast with some lessons and concepts currently being taught in university diversity courses. The results of the present study support these ideas presented throughout the literature, as they suggest that university students are willing to recognize, discuss, and capitalize on these generational differences.

Regarding the challenges identified in working with other generations, each generation also reported a second category as important, and these responses varied widely. Twenty-seven percent of Baby Boomers reported work ethic as the second largest challenge in working with other generations. Comments included some of the buzzwords typical of the stereotypes of younger generations such as "entitlement," the lack of willingness to complete physical work, and a lesser commitment to the organization. Twenty-one percent of Gen Xers reported values and beliefs were the second largest challenge. They mentioned feelings of belonging to a different culture altogether than either of the other generations included in the population, and feelings of being "stuck in the middle" of Millennials and Baby Boomers. Finally, $26 \%$ of Millennials surveyed mentioned technological skills were the second largest challenge in working with older generations. They mentioned feelings of frustration with the older generations' occasional resistance to new technology, but also expressed pride in their abilities to offer help in this area. Overall, the frustrations identified from each group were largely supported by the generational differences outlined in the Literature Review. 
Survey responses varied less as students reported the opportunities realized by working with members of different generations. Both the Baby Boomers (33\%) and Gen Xers (42\%) identified reciprocal mentoring, or the ability for members of each generation to offer some unique knowledge to members of other generations, as their second most popular choice. This response is encouraging, and the compliments given to members of other generations throughout the comments were refreshing. Both generations specifically mentioned that they enjoyed the opportunity to learn about new technologies from younger co-workers. Forty-nine percent of the Millennial group identified knowledge as the main benefit to be gained when working with older generations. Again, this is a refreshing finding, considering the rate at which Baby Boomers are retiring, and all of the knowledge and experience they are packing up and taking with them as they exit. Millennials' awareness of the value of this knowledge is a positive indication that members of the younger, larger generation of employees are aware of the value in learning from their long-tenured peers and leaders. The benefits of working in an age-diverse setting identified by participants in the present study directly support the strengths of the generations identified in the literature and suggest that the participants have a positive mindset as they capitalize on these perceived generational differences.

Overall, the comments provided by survey participants yielded a more positive view of other generations than expected, based on the stereotypes frequently highlighted in popular news sources. Throughout the existing topical literature, reciprocal mentoring is identified by researchers as the most beneficial practice to bring generations together in the workplace. The students surveyed reported that they were both experienced in working with other generations and open to this practice, affirming this as a best practice and one that should be explored with leadership students in a classroom environment.

Limitations. The main limitation of this study was sample size. A broader audience of participants could have yielded more robust results. Additionally, the students surveyed in this study came from a convenience sample, which was comprised of students currently enrolled in a program in the Department of Leadership and Organizational Administration and students who were attending a leadership skills development workshop on campus. The students attending the workshop represented majors from several disciplines, which were not recorded. Many of these students indicated that they had previous in-class experience learning about generational differences in the workplace, but this experience could have varied widely from student to student and program to program. Certainly, not all students had been exposed to the same lessons or research on this topic prior to completing the survey. Regarding the research design, the present study measured only student perceptions of workplace issues. This data cannot be interpreted to determine causes or effects of specific workplace issues at any specific employer or industry, as this information was not collected.

\section{Recommendations}

Recommendations for Educators. Based on the review of literature and the results of this study, the author offers several recommendations for leadership educators. First, educators are encouraged to have frank conversations with their students to communicate the state of generational-based stereotypes versus evidence-based differences (Chamberlin, 2009; Costanza \& Finkelstein, 2015; Gursoy, Maier, \& Chi, 2008; Perry, Golom, \& McCarthy, 2015; Twenge, 
2010). Allowing students to build on a foundation of stereotypes could limit their abilities to appreciate the strengths of each generation. Second, educating each generation about their own strengths, and what unique skills and perspectives they bring to the workplace can help students determine ways they blend well with the norms of their generational peers and ways they stand out as individuals. This information can ready students to join the workforce as self-aware individuals, able to highlight their own strengths and identify their potential weaknesses (Abrams \& von Frank, 2014). Thirdly, informing and affirming the strengths each group brings to the workplace and how these strengths can be beneficial to team decision-making can help students appreciate others, lead to better work experiences, and help to break down negative stereotypes promoted by the media (Abrams \& von Frank, 2014; Chamberlin, 2009). Readying our students for the workplace includes teaching proper content knowledge and refining soft skills. The latter process can be improved by better preparing students to work in the current, fast-changing generational landscape.

Lastly, keeping up with what employers say about areas in which new graduates excel and lack skills should help leadership educators to define and refine curriculum. Clearly the composition of the generations represented in the workforce has changed a great deal in recent times, and it is predicted to continue on a path of rapid change (Dews, 2014; Donston-Miller, 2016; Fry, 2015). Educators who are preparing leaders in the workforce may understandably find difficulty in keeping abreast of these changes in conjunction with processing feedback from employers and other stakeholders via advisory boards and/or professional associations.

Committing to addressing perceived generational differences, strengths, and challenges is also a commitment to challenging students to be introspective and seek the best in their peers. This practice can help new graduates overcome part of the gap in soft skills being identified by employers. As stated by Constanza and Finkelstein (2015):

The key to managing a multigenerational workforce effectively is for managers not to make decisions about employees using their generation as a shortcut to their characteristics and needs but rather to measure critical individual differences as well as to track the gradual developmental and demographic changes that occur within and among individuals over time (p. 317).

Recommendations for Future Research. Based on the review of literature and the results of this study, several recommendations for future research are proposed. Thus far, a proven theory of generationally-based differences has not been generally accepted in the social sciences. This is likely due to a combination of the aforementioned complexity involved in separating the factors that affect generational behavior, the rapid pace at which the composition of the workforce is changing, and the contention that generational differences are simply an alternate name for age-related diversity issues (Abrams \& von Frank, 2014; Costanza \& Finkelstein, 2015; Fry, 2015). Researchers who desire to dig deeper into these issues could find value for stakeholders of leadership education programs by conducting studies that focus on:

- Differences in student views on working with members of other generations prior to a diversity course that provides a generational component compared with their views following the diversity course. 
- Determining (and continuing to determine) the gaps between the diversity components of leadership education programs and the expectations of employers for new graduates to be able to work well with individuals from other generations.

- Creating a study that lends itself to use in specific industry areas by utilizing a more descriptive survey method to provide insights on students' perspectives based on industry experience (i.e. finance, education, politics, etc.).

\section{References}

Abrams, J. \& von Frank, V. A. (2014). The multigenerational workplace: Communicate, collaborate, and create community. Thousand Oaks, CA: Corwin. doi: $10.4135 / 9781483387741$

Andenoro, A. C., Allen, S. J., Haber-Curran, P., Jenkins, D. M., Sowcik, M., Dugan, J. P., \& Osteen, L. (2013). National Leadership Education research agenda 2013-2018: Providing strategic direction for the field of leadership education. Retrieved from Association of Leadership Educators website: http://leadershipeducators.org/ ResearchAgenda

Beutell, N.J. \& Wittig-Berman, U. (2008). Work-family conflict and work-family synergy for generation X, baby boomers, and matures: Generational differences, predictors, and satisfaction outcomes, Journal of Managerial Psychology, 23(5), 507 - 523. doi: 10.1108/02683940810884513

Brown, S. (2016). Diversity courses are in high demand. Can they make a difference? The Chronicle of Higher Education, Retrieved from https://www.chronicle.com/article/Diversity-Courses-Are-in-High/234828

Chamberlin, J. (2009). Overgeneralizing the generations. Monitor on Psychology, 40(6), 40.

Costanza, D. P. \& Finkelstein, L. M. (2015). Generationally based differences in the workplace: Is there a there there? Industrial and Organizational Psychology, 8(3), 308 - 323.

Dews, F. (2014, July 17). Brookings data now: 75 percent of 2025 workforce will be Millennials, Brookings Now. Retrieved from https://www.brookings.edu/blog/brookingsnow/2014/07/17/brookings-data-now-75-percent-of-2025-workforce-will-be-millennials/

Dimock, M. (2018). Defining generations: Where Millennials end and post-Millennials begin. Fact Tank: News in the Numbers. Retrieved from http://www.pewresearch.org/facttank/2018/03/01/defining-generations-where-millennials-end-and-post-millennials-begin/

Dishman, L. (2015). Millennials have a different definition of diversity and inclusion. Fast Company. Retrieved from https://www.fastcompany.com/3046358/millennials-have-adifferent-definition-of-diversity-and-inclusion

Dittmann, M. (2005). Generational differences at work. Monitor on Psychology, 36(6), 54. 
Donston-Miller (2016, May 5). Workforce 2020: What you need to know now, Forbes Workday Voice. Retrieved from https://www.forbes.com/sites/workday/2016/05/05/workforce2020-what-you-need-to-know-now/\#72df17f62d63

Fabris, C. (2015). College students think they're ready for the workforce. Employers aren't so sure. The Chronicle of Higher Education, Retrieved from https://www.chronicle.com/article/College-Students-Think/151289

Frey, W. H. (2016, June 28). Diversity defines the millennial generation. Brookings, Retreived from https://www.brookings.edu/blog/the-avenue/2016/06/28/diversity-defines-themillennial-generation/

Fry, R. (2015, May 11). Millennials surpass Gen Xers as the largest generation in U.S. labor force. Fact Tank: News in the Numbers. Retrieved from http://www.pewresearch.org/fact-tank/2015/05/11/millennials-surpass-gen-xers-as-thelargest-generation-in-u-s-labor-force/

Gursoy, D., Maier, T. A., \& Chi, C. G. (2008). Generational differences: An examination of work values and generational gaps in the hospitality workforce. International Journal of Hospitality Management, 27(3), 448 - 458. doi:10.1016/j.ijhm.2007.11.002

Huppke, R. (2018, January 15). What do Millennials, Gen Xers, Boomers share? Leadership values. Chicago Tribune. Retrieved from http://www.chicagotribune.com/business/cthuppke-millennials-gen-x-leadership-1116-biz-20151113-column.html

Jaschik, S. (2015, January 20). Well prepared in their own eyes. Inside Higher Ed Weekly News Update, Retrieved from https://www.insidehighered.com/news/2015/01/20/study-findsbig-gaps-between-student-and-employer-perceptions

Knight, R. (2014). Managing people from five generations. Harvard Business Review, Retrieved from https://hbr.org/2014/09/managing-people-from-5-generations

Lacey, T. A., Toossi, M., Dubina, K. S., \& Gensler, A. B. (2017). Projections overview and highlights, 2016-26, Bureau of Labor Statistics Monthly Labor Review. Retrieved from https://www.bls.gov/opub/mlr/2017/article/projections-overview-and-highlights-201626.htm

Lu, A. C. \& Gursoy, D. (2016). Impact of job burnout on satisfaction and turnover intention: Do generational differences matter? Journal of Hospitality and Tourism Research, 40(2), 210 - 235. doi: 10.1177/1096348013495696

Lynch, A. (2008). ROI on generation Y employees. Bottom Line Conversations, LLC. Retrieved from http://www.knoxvillechamber.com/pdf/workforce/ROIonGenYWhitePaper.pdf

Lynch, M. (2016, January 16). Four reasons why classrooms need diversity education. The Edvocate, Retrieved from http://www.theedadvocate.org/4-reasons-classrooms-needdiversity-education/

Meister, J. C. \& Willyerd, K. (2010). Mentoring Millennials. Harvard Business Review, Retrieved from https://hbr.org/2010/05/mentoring-millennials 
O'Shaughnessy, L. (2015). New college grads: Who employers want to hire. CBS News Moneywatch. Retrieved from http://www.cbsnews.com/news/new-college-grads-whoemployers-want-to-hire/

Perry, E. L., Golom, F. D., \& McCarthy, J. A. (2015). Generational differences: Let's not throw the Baby Boomer out with the bathwater, Industrial and Organizational Psychology, $8(3), 376-382$.

The Whys and Hows of Generations Research (2015, September 3). Pew Research Center. Retrieved from http://www.people-press.org/2015/09/03/the-whys-and-hows-ofgenerations-research/

Thompson, C. \& Gregory, J. B. (2012). Managing Millennials: A framework for improving attraction, motivation, and retention. The Psychologist-Manager Journal, 15(4), 237 246. doi: 10.1080/10887156.2012.730444

Twenge, J. M. (2010). A review of the empirical evidence on generational differences in work attitudes. Journal of Business \& Psychology, 25(2), 201-210. doi: 10.1007/s10869-0109165-6

Zimmerman, K. (2016). Modern Mentoring is the Key to Retaining Millennials. Forbes. Retrieved from https://www.forbes.com/sites/kaytiezimmerman/2016/07/18/modernmentoring-is-the-key-to-retaining-millennials/2/\#60acc36526c7

\section{Author Biography}

Dr. Kathryn Woods (woodsk@apsu.edu) is an Associate Professor for the Department of Leadership and Organizational Administration at Austin Peay State University. Her courses focus on leadership development, organizational innovation, ethical leadership, and small group leadership. Her current research interests include social media, organizational behavior, leadership development, digital leadership profiles, online learning, and non-traditional students. 